\title{
Pawel Lewandowski
}

\section{DELEGOWANIE CZLONKA RADY NADZORCZEJ SPÓŁKI Z OGRANICZONĄ ODPOWIEDZIALNOŚCIĄ DO PELNIENIA FUNKCJI W ZARZĄDZIE}

\begin{abstract}
Streszczenie
Dotychczas nie zostało jednoznacznie przesądzone, czy w spółce z ograniczoną odpowiedzialnością jest dopuszczalne delegowanie członka rady nadzorczej do czasowego wykonywania funkcji członka zarządu. Praktyka wskazuje na taką możliwość, w doktrynie zaś wyrażane są różne poglądy w tej materii.

Celem pracy uczyniono analizę przedmiotowego zagadnienia. Zwrócono uwagę na zasadę wolności umów na gruncie prawa spółek oraz różnice występujące w regulacji spółek osobowych i kapitałowych, w tym w sposobie powoływania zarządu. Omówiono konsekwencje oceny delegowania wobec braku wyraźnej regulacji, jak i braku odesłania do stosowania per analogiam art. 383 k.s.h. Wskazano na wiele wątpliwości, jakie wywołuje delegowanie (w przypadku aprobaty tezy o jego dopuszczalności), w szczególności status osoby delegowanej (kwestia dalszego trwania stosunku prawnego w radzie nadzorczej). W pracy zastosowano metodę dogmatyczną.

W konkluzji stwierdzono, że delegowanie członka rady nadzorczej w spółce z ograniczoną odpowiedzialnością de lege lata nie jest dopuszczalne. Jest jednak pożądane, wobec czego powinno zostać uregulowane na wzór art. $383 \S 1$ k.s.h.
\end{abstract}

Słowa kluczowe: spółka z ograniczoną odpowiedzialnością, rada nadzorcza, zarząd, zasada wolności umów

* dr Paweł Lewandowski, Wydział Prawa i Administracji, Uniwersytet Warmińsko-Mazurski w Olsztynie, adres email: pawel.lewandowski@uwm.edu.pl; ORCID: 0000-0002-8979-928X 


\section{Wprowadzenie}

Spółka z ograniczoną odpowiedzialnością ${ }^{1}$ działa $\mathrm{w}$ obrocie gospodarczym, korzystając z przyznanej jej osobowości prawnej (art. 12 kodeksu spółek handlo$w_{y c h}^{2}$ ). Posiada zatem strukturę organów wyposażonych w określone kompetencje i umocowanych do dokonywania czynności dla nich przeznaczonych (art. 38 kodeksu cywilnego ${ }^{3}$ ). Zarząd w spółce $\mathrm{z}$ o.o. jest organem obligatoryjnym ${ }^{4}$, natomiast rada nadzorcza ${ }^{5}$ - co do zasady - fakultatywnym ${ }^{6}$.

Zarząd jest organem jedno- bądź wieloosobowym. W obu przypadkach może się zdarzyć, że żaden z członków zarządu nie będzie mógł sprawować mandatu, a przy tym nie będzie możliwości natychmiastowego powołania nowego członka zarządu. Tymczasem bez prawidłowo obsadzonego zarządu spółka z o.o. nie może funkcjonować i uczestniczyć w obrocie. W takich okolicznościach w odniesieniu do omawianej spółki ustawodawca poza możliwością powołania nowego członka zarządu nie przewiduje innych szczególnych form uzupełnienia składu tego organu. Przede wszystkim nie wskazuje na możliwość delegowania członka RN do czasowego wykonywania czynności w zarządzie, co zostało expressis verbis wyrażone w przypadku spółki akcyjnej. Brak w regulacji spółki z o.o. przepisu analogicznego do art. 383 k.s.h. stanowi oś sporu i powoduje, że możliwe są różne kierunki wykładni obowiązującego stanu prawnego.

Wątpliwości w materii delegowania członka $\mathrm{RN}$ do wykonywania czynności zarządu przesiąkły do obecnych rozważań z kodeksu handlowego ${ }^{7}$. Już wówczas część autorów uważała, że umowa spółki może upoważnić $\mathrm{RN}$ do dele-

1 Dalej jako spółka z o.o.

2 Ustawa z 15 września 2000 r. Kodeks spółek handlowych, Dz.U. z 2019 r., poz. 505 ze zm., dalej k.s.h.

3 Ustawa z 23 kwietnia 1964 r. Kodeks cywilny, Dz.U. z 2019 r., poz. 1145 ze zm., dalej k.c.

4 Zarząd jest organem „wykonawczym”, mającym umocowanie do prowadzenia spraw spółki i jej reprezentacji; korzysta przy tym z domniemania kompetencji, co oznacza, że sprawy, które nie zostały wprost zastrzeżone do kompetencji innych organów, przynależą do zarządu, por. A. Rachwał, w: System Prawa Handlowego, t. 2 A Prawo spółek handlowych, red. S. Włodyka, Warszawa 2007, s. 962 i n.

5 Dalej RN.

6 O przypadkach obligatoryjnego występowania RN stanowi art. 213 § 2 k.s.h.

7 Rozporządzenie Prezydenta Rzeczypospolitej z 27 czerwca 1934 r. Kodeks Handlowy, Dz.U. z 1934 r., nr 57, poz. 502 ze zm., dalej k.h. 
gowania swoich członków do czasowego wykonywania czynności zarządu ${ }^{8}$, inni zaś uznawali, że przenoszenie instytucji regulowanych w odniesieniu do spółki akcyjnej na spółkę z o.o. nie jest dopuszczalne ${ }^{9}$. Jest zastanawiające, dlaczego mimo istniejących rozbieżności ustawodawca nie uregulował kwestii delegowania w spółce z o.o. w obowiązującym k.s.h.

Zaprezentowane stanowisko ma na celu wykazanie, że delegowanie członka $\mathrm{RN}$ w spółce z o.o. de lege lata nie jest dopuszczalne. Sprzeciwia się zatem praktycznemu podejściu do zagadnienia ${ }^{10}$, jednak znajduje jurydyczne oparcie w porządku prawnym.

\section{Stanowisko doktryny w zakresie dopuszczalności delegowania}

\section{Zasada swobody umów}

Podjęte zagadnienie powiązane jest ze spojrzeniem na zasadę swobody umów na gruncie prawa spółek. Stanowi bądź argument za akceptacją poglądu o dopuszczalności delegowania członka RN do pełnienia funkcji zarządu, bądź przeszkodę ku temu. Przedstawiciele doktryny, według których dopuszczalne jest w spółce z o.o. delegowanie członka $\mathrm{RN}$ do pełnienia funkcji członka zarządu, jako główny argument wskazują zasadę swobody umów. Podstawą zastosowania przepisu art. $353^{1}$ k.c. do prawa handlowego jest odesłanie do k.c. przez art. 2 k.s.h. (prawo handlowe jest częścią prawa cywilnego) ${ }^{11}$. O ile w odniesieniu do spółki akcyjnej swoboda umów po myśli art. 304 § 3 i 4 k.s.h. została wyraźnie ograniczona, o tyle w odniesieniu do spółki z o.o. analogicznego przepisu brak. $\mathrm{Na}$ tej podstawie wnioskuje się, że zasada autonomii woli znajduje zastosowanie

8 T. Dziurzyński, w: Kodeks handlowy. Komentarz, red. T. Dziurzyński, Z. Fenichel, M. Honzatko, Łódź 1995, s. 241.

9 J. Namitkiewicz, Kodeks handlowy. Komentarz t. III, Warszawa 1937, s. 155; M. Allerhandt, Kodeks handlowy. Księga pierwsza Kupiec. Komentarz, Lwów 1935 (reprint Warszawa 1991), s. 345. Niejednoznacznie wypowiadają się J. Tomkiewicz i J. Bloch, wskazując, że RN w przypadku zdekompletowania zarządu na skutek zawieszenia członków zarządu winna podjąć kroki celem uzupełnienia składu zarządu, odwołując się do art. 383 § 1 k.h., w: Spółki z ograniczona odpowiedzialnością. Kodeks handlowy art. 158-306 i 491-497. Komentarz, red. J. Tomkiewicz, J. Bloch, Warszawa 1934, s. 119.

10 Por. stan faktyczny sprawy toczonej przed SN, wyrok SN z 6 czerwca 2013, II UK 329/12, lex nr 1331292.

11 K. Kopaczyńska-Pieczniak, w: Kodeks spótek handlowych t. I. Komentarz do art. 1-150, red. A. Kidyba, Warszawa 2017, s. 54. 
w odniesieniu do kształtowania treści postanowień umowy spółki z o.o. ${ }^{12}$ Część komentatorów podnosi, że uregulowanie kwestii delegowania w drodze stosownych zapisów umowy spółki nie sprzeciwia się ograniczeniom wynikającym $\mathrm{z}$ art. $353^{1}$ k.c., w szczególności naturze spółki z o.o. ${ }^{13} \mathrm{~W}$ związku z tym, brak odpowiednika art. 383 k.s.h. nie świadczy o niedopuszczalności delegowania, bowiem tego ustawodawca nie zakazał na podstawie klauzuli generalnej.

Niektórzy autorzy uzależniają zastosowanie art. $353^{1}$ k.c. od liczebności wspólników, dopuszczając powołanie się na tę zasadę wyłącznie względem spółek innych niż jednoosobowa ${ }^{14}$, gdyż w takiej sytuacji nie można mówić o umowie spółki sensu stricto. Pogląd ten, z uwagi na brzmienie przepisu art. 4 $\S 2$ k.s.h., który wprowadza równość pomiędzy aktem założycielskim i umową spółki, jest słusznie kwestionowany. Uznaje się, że wskazane dokumenty mają identyczny charakter jurydyczny, a ich rozróżnienie znajduje uzasadnienie jedynie w nazwie ${ }^{15}$. Należy zgodzić się, że przywołane stanowisko stanowi wykładnię contra legem, co dodatkowo prowadzi do powstania nierówności spółek $\mathrm{z}$ o.o. W kwestii tej ustawodawca nie wprowadza dystynkcji, posługując się nią w sposób wyraźny w sytuacjach tego wymagających (np. art. $210 \S 2$ k.s.h.). A contrario w pozostałych sytuacjach możliwość przenoszenia regulacji pomiędzy spółkami jest niewłaściwa.

Przedstawiciele doktryny, według których zasada swobody umów jest w prawie spółek ograniczona, wskazują, że prawo spółek nie jest oparte na zasadzie suwerenności i samorządności. Powołując się na bezpieczeństwo obrotu oraz kreacyjny charakter umowy spółki handlowej (wykreowanie niezależnej i samodzielnej jednostki organizacyjnej wyposażonej w podmiotowość), ustawodawca pozostawia sobie szerokie kompetencje do ingerencji w treść umowy spółki, przekazując wspólnikom wąski zakres swobody kreacji stosunku spółki ${ }^{16}$.

12 R.L. Kwaśnicki, Autonomia woli w ksztaltowaniu postanowień umowy (aktu założycielskiego) spótki z o.o., „Prawo Spółek” 2003, nr 7-8, s. 20, 36.

13 K. Strzelczyk, w: Kodeks spółek handlowych. Komentarz, t. 2, red. T. Siemiątkowski, R. Potrzeszcz, Warszawa 2011, s. 402; M. Rodzynkiewicz, Kodeks spótek handlowych komentarz, Warszawa 2012, s. 406-407.

14 M. Litwińska, Glosa do wyroku Sądu Najwyższego z 5 maja 1996 r., sygn. akt: II CRN 29/96, „Przegląd Prawa Handlowego” 1997, nr 1, s. 28.

15 Por. R.L. Kwaśnicki, op.cit., s. 20; por. T. Siemiątkowski, R. Potrzeszcz, w: Kodeks spółek handlowych. Komentarz, t. 1, red. T. Siemiątkowski, R. Potrzeszcz, Warszawa 2011, s. 48.

16 M. Romanowski, w: System Prawa Prywatnego t. 16. Prawo spótek osobowych, red. A. Szajkowski, Warszawa 2008, s. 176-177. 
Prowadzi to do twierdzenia, iż ustawodawca nie uważa, że to wspólnicy najlepiej wiedzą, w jaki sposób ukształtować treść umowy spółki ${ }^{17}$. W spółkach kapitałowych jako zasadę wskazującą na ich naturę podnosi się rozdzielenie kompetencji pomiędzy organami spółki. Zatem wszelkie odstępstwa w tej materii traktować należy w sposób możliwie precyzyjny. Każdy organ spółki ma swoje własne, ustawowo zastrzeżone kompetencje, które mogą być modyfikowane w przypadku występowania normy prawnej w tym zakresie. W związku z tym uznaje się, że nawet przykładowy (otwarty) charakter wyliczenia dodatkowych kompetencji RN (art. 220 k.s.h.) świadczy o tym, że delegowanie (które nie zostało wymienione w katalogu art. 220 k.s.h.) znajduje się poza swobodą kontraktową stron ${ }^{18}$, jako wykraczające poza naturę spółki z o.o. Zatem delegowanie członków RN do czasowego wykonywania funkcji w zarządzie nie jest dopuszczalne, ponieważ na podstawie umowy spółki nie można rozszerzać kompetencji organu nadzorczego względem ustawowego modelu ${ }^{19}$. Wynika to z postrzegania rozdzielenia kompetencji organu zarządzającego i nadzorczego jako regulacji świadczącej o istocie spółki z o.o. ${ }^{20}$, w której szersze uprawnienia i silniejszą pozycję przypisuje się wspólnikom ${ }^{21}$.

\section{Sposób regulacji spółek w k.s.h.}

Przy wykładni zagadnienia dopuszczalności delegowania członka RN spółki z o.o. do pełnienia funkcji w zarządzie należy uwzględnić sposób regulacji spółek osobowych i kapitałowych. Trzeba podkreślić, że wszystkie spółki osobowe, za wyjątkiem spółki jawnej, regulowane są w sposób kadłubowy, tj. przez odesłanie do odpowiedniego stosowania przepisów o spółce jawnej ${ }^{22}$. Kodeks reguluje jedynie ich differentia specifica. Z kolei w odniesieniu do spółek kapitałowych ustawodawca posługuje się inną techniką legislacyjną, gdyż każda ze spółek regulowana jest kompleksowo, bez stosowania odesłania (przepisy ustawy stano-

\footnotetext{
17 Ibidem, s. 177.
}

18 A. Nowacki, Komentarz do art. 220 KSH, w: Spółka z ograniczoną odpowiedzialnością. Tom I. Komentarz do art. 151-226 KSH, Legalis 2018.

19 M. Tarska, Zakres swobody umów w spółkach handlowych, Warszawa 2012, s. 404.

20 A. Szumański, Ograniczenia wolności umów w prawie spółek handlowych, „Gdańskie Studia Prawnicze" 1999, t. II, s. 417; M. Tarska, op.cit., s. 404.

21 Por. art. 212 k.s.h., którego odpowiednika brak w przypadku spółki akcyjnej.

22 Art. 89 k.s.h., art. $103 \S 1$ k.s.h., art. $126 \S 1$ pkt 1 k.s.h. odsyłają do odpowiedniego stosowania przepisów o spółce jawnej. 
wią funkcjonalną całość). W tym kontekście wątpliwe jest sięganie na potrzeby spółki z o.o. do wzorców spółki akcyjnej ${ }^{23}$. Skoro ustawodawca nie stosuje przepisów odsyłających do innej spółki kapitałowej, to należy sądzić, że nie jest możliwe czerpanie z jej regulacji. Dopuszczenie takiej możliwości świadczyłoby o tym, że przepisy odsyłające przy regulacji spółki partnerskiej, komandytowej i komandytowo-akcyjnej są zbędne, gdyż „odesłanie” i tak następuje bez nich.

Zgodzić należy się z poglądem, że natura spółki z o.o. i spółki akcyjnej są odmienne, mimo że obie są spółkami kapitałowymi ${ }^{24}$. W przypadku spółki akcyjnej ustawodawca expressis verbis przewidział i uregulował delegowanie, czego nie uczynił w odniesieniu do spółki z o.o. Przy racjonalności ustawodawcy dowodzi to celowości zabiegu legislacyjnego, a tym samym przyjęcia, że ustawodawca nie zamierzał legalizować delegowania w spółce z o.o. ${ }^{25}$ Warto zauważyć, że art. 220 k.s.h i art. 383 k.s.h. wykazują pewne podobieństwo, co może potwierdzać, że przywołana odmienność nie jest przypadkowa ${ }^{26}$. Zdaniem niektórych autorów fakt, że wyliczenie wskazane w art. 220 k.s.h. ma charakter przykładowy, nie pozwala na przyjęcie stanowiska, że delegowanie jest zakazane $^{27}$. Wskazuje się jednak, że wyczerpujące i dokładne uregulowanie uprawnień RN prowadzi do wniosku, że wyliczenie to stanowi maksymalny katalog kompetencji wpływających na funkcjonowanie i kształt zarządu ${ }^{28}$. Ponadto rozdział kompetencji pomiędzy organami oraz ich ustawowe dookreślenie (w tym w odniesieniu do organu nadzorczego) stanowią element świadczący o istocie spółki z o.o., wobec czego nie mogą być umownie rozszerzane ${ }^{29}$. Przekonujące

23 Przeciwnie twierdzą A. Szajkowski, M. Tarska, A. Szumański, podnosząc, że niektóre kwestie (wśród nich delegowanie członka RN do wykonywania czynności zarządu) celowo znalazły się poza tekstem ustawy, gdyż spółka z o.o. jest słabiej „doregulowana” niż spółka akcyjna. Dlatego możliwe jest sięganie do wzorców spółki akcyjnej przy niemożności jej stosowania w odwrotnym kierunku, gdyż gro regulacji spółki z o.o. nie przystaje do istoty spółki akcyjnej, w: Kodeks spótek handlowych t. II. Spótka z ograniczona odpowiedzialnościa. Komentarz do art. 151-300, red. S. Sołtysiński, A. Szajkowski, A. Szumański, J. Szwaja, Warszawa 2014, s. 575-576.

24 A. Szumański, Ograniczenia..., s. 416.

25 J.A. Strzępka, E. Zielińska, w: Kodeks spótek handlowych. Komentarz, red. J.A. Strzępka, Warszawa 2015, s. 556; W. Strzępka, Rozszerzenie uprawnień rady nadzorczej w spótce z o.o., „Prawo Spółek” 2001, nr 5, s. 26.

26 A. Nowacki, Komentarz...

27 M. Rodzynkiewicz, op.cit., s. 406.

28 K. Kopaczyńska-Pieczniak, w: Kodeks spółek handlowych t. II. Komentarz do art. 151-300, red. A. Kidyba, Warszawa 2018, s. 497.

29 M. Tarska, op.cit., s. 404. 
są argumenty o zamkniętym katalogu spółek handlowych, z regulacji których nie można dowolnie selekcjonować elementów i transferować ich do innych form prawnych, o ile nie zezwala na to sam ustawodawca. Okoliczność kreacyjnego charakteru umowy nie może pozostać bez wpływu na swobodę umowy. Ponadto zgodzić należy się ze stwierdzeniem, że „ryzyko dla spółki, wspólników oraz osób trzecich, jakie wiąże się z wykorzystaniem omawianej instytucji, przemawia przeciwko uznaniu dopuszczalności delegowania członków rady nadzorczej do czasowego wykonywania czynności członków zarządu w spółce z o.o. na podstawie umowy spółki"30.

W tym miejscu warto przywołać Rekomendację Zespołu do opracowania rekomendacji w zakresie projektu przepisów regulujących prostą spółkę akcyjną (propozycja zmian w Kodeksie spółek handlowych) ${ }^{31}$. Dokument ten przewiduje nowy model spółki kapitałowej, tj. prostej spółki akcyjnej ${ }^{32}$. Rekomendacja stanowi w sposób wyraźny o możliwości delegowania w PSA (art. 30066 Rekomendacji stanowi odpowiednik art. 383 k.s.h.), nie pozostawiając dowolności interpretacyjnej, a nawet rozwiązując pewne istniejące dotychczas wątpliwości w zakresie delegowania. Planowana regulacja stanowi potwierdzenie, że ustawodawca, mając w zamiarze dopuszczenie delegowania członka RN do czasowego wykonywania funkcji w zarządzie, czyni to wyraźnie. Pozwala to zatem na wyprowadzenie wniosku, że brak regulacji w zakresie delegowania w spółce z o.o. nie jest przypadkowy, lecz stanowi celowy zamysł ustawodawcy.

O braku przypadkowości obecnej regulacji świadczy wykładnia historyczna. Kodeks handlowy nie regulował delegowania w odniesieniu do spółki z o.o., czyniąc to w przypadku spółki akcyjnej ${ }^{33}$. Istniejące w tej materii rozbieżności nie skłoniły ustawodawcy do uregulowania analizowanego zagadnienia. Wydaje się, że ustawodawca posłużył się regulacją negatywną ${ }^{34}$, a mianowicie nie chcąc, aby delegowanie w spółce z o.o. było stosowane, po prostu ani wyraźnie na to nie wskazał, ani nie dopuścił tego w formie przepisu odsyłającego. Nie sposób zatem wbrew ustawodawcy twierdzić, że w sytuacji braku przepisu możliwe jest

\section{Ibidem, s. 405.}

31 Rekomendacja wprowadza zmiany w innych częściach kodeksu - związanych z PSA nie ingeruje w treść art. 220 k.s.h., niepublikowany.

32 Dalej PSA.

33 Por. W. Strzępka, op.cit., s. 28.

34 Por. L. Morawski, Zasady wyktadni prawa, Toruń 2010, s. 150. 
wykreowanie ku temu normy kontraktowej, jakby w tym zakresie zaistniała luka prawna, którą należy w jakiś sposób wypełnić.

\section{Argument z kompetencji do powoływania zarządu}

Na przepis art. 383 k.s.h. oraz brak jego odpowiednika w dziale I tytułu III k.s.h. spojrzeć należy także przy uwzględnieniu regulacji art. 368 § 4 k.s.h. i art. 201 $\S 4$ k.s.h., wskazujących podmioty uprawnione z mocy ustawy do powoływania i odwoływania członków zarządu. O ile w spółce akcyjnej uprawnienie (ale także obowiązek, por. art. $383 \S 2$ k.s.h..$^{35}$ ) do powołania członków zarządu przyznane zostało RN, to w spółce z o.o. co do zasady - wspólnikom (art. 201 § 4 k.s.h. ma charakter dyspozytywny ${ }^{36}$ i umowa może upoważnić inny podmiot, $\mathrm{w}$ tym $\mathrm{RN}$, do powołania członków zarządu). W spółce z o.o. to zgromadzenie wspólników, z założenia, powinno mieć wpływ na skład zarządu, a tym samym kształt i obraz spółki. W tym kontekście wykładnia pozytywna, tj. dopuszczająca delegowanie członka RN do czasowego wykonywania czynności zarządu na gruncie spółki z o.o., wydaje się sprzeczna z zamierzeniem ustawodawcy. Przyznanie powyższej kompetencji RN wprowadza wyłom w systemowe ujęcie kompetencji organów powołujących piastunów zarządu, sprawiając, że organ, który nie ma ex lege uprawnienia do powołania organu, ma kompetencję do jego uzupełnienia w sytuacji wyjątkowej. Wykładnia taka jawi się jako przypadkowa i naruszająca spójność kodeksu w tej materii, gdyż rola RN w spółce akcyjnej została, na podstawie art. $368 \S 4$ k.s.h, wyraźnie wzmocniona względem spółki z o.o. o istotne uprawnienia personalne ${ }^{37}$. Z powołaniem związane jest jednocześnie ich odwołanie $\mathrm{i}$ w te kompetencje systemowo wpisuje się uprawnienie do czasowego delegowania w związku ze zdekompletowaniem członków organu wykonawczego.

35 Autorzy podają, że na RN ciąży obowiązek dokonywania zmian w składzie zarządu (konieczność działania rady dla dobra spółki), w zakres pojęciowy którego wchodzi także delegowanie, por. J. Szwaja, I.B. Mika, w: Kodeks spółek handlowych. Tom III. Spółka akcyjna. Komentarz do art. 301-490, red. S. Sołtysiński, A. Szajkowski, A. Szumański, J. Szwaja, Warszawa 2013, s. 733.

36 Wyjątkiem od tej reguły są komunalne spółki z o.o., w których członków zarządu powołuje rada nadzorcza, art. 10a ust 6 ustawy z dnia 20 grudnia 1996 r. o gospodarce komunalnej, Dz.U. z 2019 r., poz. 712 ze zm.

37 A. Szajkowski, M. Tarska, A. Szumański, w: Kodeks spótek handlowych. Tom III..., s. 570. 


\section{Wątpliwości związane z delegowaniem w praktyce}

Brak zarówno wyraźnej regulacji delegowania członka $\mathrm{RN}$ do pełnienia funkcji zarządu w spółce z o.o., jak i wskazania co do stosowania art. 383 k.s.h. per analogiam wywołuje wiele niejasności nie tylko co do dopuszczalności tej instytucji w spółce z o.o., ale również co do przesłanek delegowania i oceny jego konsekwencji prawnych w przypadku aprobaty tezy o jego dopuszczalności. W literaturze przedmiotu prezentowane są różne teorie co do statusu delegowanego członka (chociaż właściwe dla spółki akcyjnej, aktualne także na gruncie spółki $\mathrm{z}$ o.o.). Istniejące wątpliwości nie przemawiają za dopuszczalnością delegowania w spółce z o.o.

\section{Delegowanie jako instytucja wyjątkowa}

Wymaga podkreślenia, że delegowanie regulowane na gruncie spółki akcyjnej jest postrzegane jako instytucja wyjątkowa, dopuszczalna w sytuacji, gdy zarząd nie może prawidłowo funkcjonować ${ }^{38}$. Konkretnie chodzi o czasową tylko przeszkodę w sprawowaniu funkcji członka zarządu, a nie o definitywną niemożność (ta nie mieści się $\mathrm{w}$ ustawowej przesłance delegowania) ${ }^{39}$. W związku z tym, gdy zarząd jest należycie obsadzony, delegowanie nie może nastąpić w celu na przykład kadrowego wsparcia zarządu ${ }^{40}$. Delegowanie jest możliwe, gdy członek zarządu nie może obecnie sprawować mandatu, lecz istnieje szansa na jego przywrócenie w możliwym do określenia, lecz nieodległym czasie ${ }^{41}$. Delegowanie nie powinno być dopuszczalne w sytuacji, gdy czas przywrócenia członka zarządu do sprawowania funkcji jest co prawda możliwy do określenia (przewidywalny), ale odległy ${ }^{42}$.

38 J.P. Naworski, Delegowanie członków organów nadzoru spółki kapitałowej do zarządu, „Prawo Spółek” 2002, nr 2, s. 3.

39 Możliwość delegowania jest wyłączona np. w razie wygaśnięcia mandatu na skutek śmierci (nie budzi wątpliwości, że osoba sprawująca funkcję członka zarządu nie powróci do wykonywania mandatu), zob. A. Szumański, w: Prawo spótek, red. W. Pyzioł, A. Szumański, I. Weiss, Warszawa 2014, s. 998.

40 A. Opalski, w: Kodeks spółek handlowych. Tom IIIA. Spółka akcyjna. Komentarz do art. 301-392, red. A. Opalski, Warszawa 2016, s. 1490.

41 Por. J.P. Naworski, op.cit., s. 6 i n.

42 Ibidem, s. 4. 
Wskazać należy, że pomimo swojej wyjątkowości delegowanie do czasowego wykonywania czynności w zarządzie jest instytucją samodzielną, nie wymaga współwystępowania $\mathrm{z}$ inną czynnością, na przykład zawieszeniem członka zarządu ${ }^{43}$. Okoliczność wprowadzająca potrzebę delegowania jest zatem irrelewantna i nie podlega badaniu.

Instytucję delegowania postrzegać należy jako wyjątek od ogólnych reguł powoływania członków zarządu w procedurze zapewniającej stabilizację jego składu osobowego. W związku z tym nie może być stosowana w zakresie szerszym niż przewiduje to ustawodawca (exceptiones non sunt extendendae). Postrzeganie delegowania jako wyjątku, przy braku wyraźnej regulacji w odniesieniu do spółki z o.o., nakazuje sądzić, że ustawodawca preferuje stosowanie „zwyczajnych” procedur w zakresie powołania nowego członka.

\section{Obowiązek wpisu delegowania do rejestru przedsiębiorców}

$\mathrm{W}$ odniesieniu do spółki z o.o. ${ }^{44} \mathrm{~W}$ rejestrze nie przewidziano stosownej rubryki na dane osób delegowanych do wykonywania czynności zarządu (nie ma fizycznie wyodrębnionego miejsca do dokonania stosownego wpisu). W przypadku delegowania stosowna informacja zamieszczana jest $\mathrm{w}$ dziale 2, podrubryce 1 rubryki 1, w polu określającym funkcję w organie reprezentującym. Taka praktyka jawi się jako niesłuszna, gdyż określenie „członek rady nadzorczej delegowany do pełnienia funkcji prezesa" nie określa funkcji, a status osoby. Z drugiej strony przyjęcie prawidłowości tej praktyki, rozwiewałoby wątpliwości w zakresie statusu tej osoby, gdyż należałoby uznać, że staje się on członkiem zarządu, skoro uzyskuje wpis w rubryce 1 odnoszącej się do organu uprawnionego do reprezentacji. Widać jednak kaskadowość i ewentualność założeń przyświecających powyższym wywodom.

Z uwagi na pewność obrotu i ochronę interesów osób trzecich (kontrahentów spółki) ustawa powinna przewidywać obowiązek wpisu delegowania członka

43 R.L. Kwaśnicki, M. Korniluk, Delegowanie członka rady nadzorczej spółki akcyjnej do czasowego wykonywania funkcji członka zarzadu, „Monitor Prawniczy” 2009, nr 1, Legalis; podobnie: J. Bieniak, w: Spółka akcyjna. Komentarz, red. J. Bieniak, M. Bieniak, Warszawa 2005, s. 308.

44 Art. 39 ustawy z 20 sierpnia 1997 r. o Krajowym Rejestrze Sądowym, Dz.U. z 2019 r., poz. 1500 ze zm., nie różnicuje w tym zakresie spółek kapitałowych, tak więc również w odniesieniu do spółki akcyjnej brak stosownej normy prawnej nakazującej dokonanie wpisu, jak i rubryki w samym rejestrze. 
$\mathrm{RN}$ do czasowego wykonywania funkcji w zarządzie spółki z o.o. Wpis powinien mieć charakter obligatoryjny, choć deklaratoryjny, a samo delegowanie powinno wywierać skutek z momentem podjęcia uchwały przez RN. Przyjąć bowiem należy, że podjęcie uchwały przez RN powinno wywierać skutek oddelegowania.

\section{Granice czasowe delegowania}

Obecny stan (nie)regulacji delegowania w spółce z o.o., w szczególności wobec dopuszczenia delegowania na zasadzie wolności umów, powoduje między innymi dowolność kształtowania granic czasowych omawianej instytucji. Podczas gdy przepis art. 383 k.s.h. expressis verbis wskazuje na czasowy charakter delegowania, dopuszczając jego stosowanie na maksymalny okres trzech miesięcy, to w przypadku spółki z o.o. nie ma legalnych wskazań w zakresie okresu dopuszczalności delegowania. Sprawia to, że możliwe wydaje się wskazanie granicy czasowej na okres wykraczający poza limit określony dla spółki akcyjnej albo np. przez odwołanie do bliżej nieokreślonego zdarzenia w przyszłości, jak chociażby określenie na dzień zwołania najbliższego zgromadzenia wspólników.

Instytucja delegowania, jako wyjątkowa, musi mieć charakter czasowy, ściśle określony. Pożądane jest jej ustawowe uregulowanie, wywołuje bowiem - jak widać - ryzyko dowolności i arbitralności kazuistycznych rozwiązań.

\section{Status członka RN delegowanego do wykonywania czynności zarządu}

Część doktryny wskazuje, że delegowany członek RN wstępuje w prawa i obowiązki członka zarządu, co jednak nie rozstrzyga o nabyciu statusu członka zarządu ${ }^{45}$. Przemawia za tym literalna wykładnia przepisu art. 383 k.s.h., w którym mowa jest o „delegowaniu do wykonywania czynności członków zarządu”, nie zaś o delegowaniu do zarządu ${ }^{46}$. Pojawiają się głosy, że gdyby zamiarem ustawodawcy była chęć uczynienia z osoby delegowanej członka zarządu, wprost wskazałby na to w tekście ustawy, zamiast posługiwać się dłuższą formą językową, odnoszącą się wprost do sprawowania czynności członka zarządu ${ }^{47}$. Jed-

45 A. Opalski, w: Kodeks spótek handlowych. Tom IIIA...., s. 1486; M. Chomiuk, w: Kodeks spótek handlowych. Komentarz, red. Z. Jara, Warszawa 2014, s. 874; podobnie na gruncie spółki akcyjnej: J. Szwaja, I.B. Mika, w: Kodeks spótek handlowych. Tom III..., s. 729.

46 A. Nowacki, Delegowanie członków rady nadzorczej do czasowego wykonywania czynności członków zarządu, „Przegląd Prawa Handlowego” 2010, nr 10, s. 13.

47 Ibidem. 
nocześnie obecny brak regulacji (przepisu) uniemożliwia przyjęcie zawieszenia delegowanego w sprawowaniu funkcji w RN przy jednoczesnym delegowaniu do zarządu i głosach świadczących o braku nabycia statusu członka zarządu, co powoduje naruszenie zasady rozgraniczenia kompetencji organów spółki ${ }^{48}$.

Z kolei drugie stanowisko uznaje osobę delegowaną za członka zarządu, twierdząc, że wykonywanie czynności członka zarządu sprawia, że się nim staje $^{49}$. Przyjmuje się, że oddelegowany członek RN staje się zarządcą z wszystkimi wynikającymi z tego konsekwencjami, a zatem już z momentem podjęcia stosownej uchwały staje się członkiem zarządu ${ }^{50}$. Delegowany wstępuje w ogół praw i obowiązków członka zarządu ${ }^{51}$. Również $\mathrm{w}$ orzecznictwie uznaje się osobę delegowaną za członka zarządu w rozumieniu art. $116 \S 1$ ordynacji podatkowej ${ }^{52}$, będącego treściowym odpowiednikiem art. 299 k.s.h.

Zaaprobowanie jednego $\mathrm{z}$ dwóch ww. stanowisk odnośnie do statusu osoby delegowanej nie jest zagadnieniem czysto doktrynalnym, lecz oddziałuje na funkcjonowanie spółki, w szczególności na kwestie odpowiedzialności osoby delegowanej za zobowiązania spółki oraz na możliwość zastosowania w stosunku do niej zakazu konkurencji. Konsekwencją aprobaty koncepcji, że delegowany członek RN nie uzyskuje statusu członka zarządu, byłoby wyłączenie w stosunku do takiej osoby stosowania niektórych regulacji, np. w zakresie wynagrodzeń, zakazu konkurencji, prowadzenia sporów ze spółką lub odpowiedzialności ${ }^{53}$. Zatem gdy względem członka RN nie wprowadzono zakazu konkurencji, to ów zakaz nie będzie go wiązał w przypadku delegowania (art. 390 $\S 3$ zd 3 k.s.h.). A contrario, nawet jeśli nie wprowadzono stosownego zakazu umownego, a uznamy, że delegowany członek RN staje się członkiem zarządu, to zakaz konkurencji będzie go obowiązywał w okresie delegowania i ustanie po tym czasie (art. $211 \S 1$ k.s.h.; czasowy charakter zakazu konkurencji) ${ }^{54}$. Zatem przyznanie, że osoba delegowana staje się członkiem zarządu, niweluje niedoskonałości legislacyjne w tej materii.

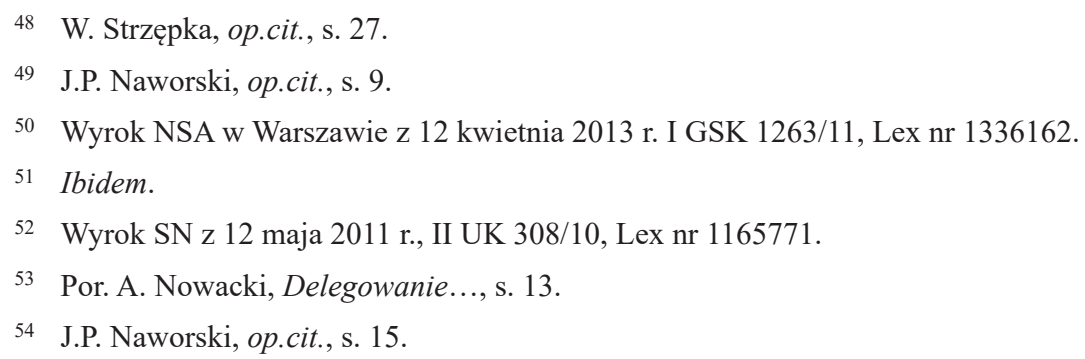


Warto w tym miejscu przywołać nowelizację k.s.h. ${ }^{55}$ dodającą art. $299^{1}$ k.s.h., mocą którego rozciągnięto odpowiedzialność członków zarządu z art. 299 k.s.h. także na likwidatorów spółki. Zmiana ta dowodzi, iż krąg podmiotów odpowiedzialnych na podstawie art. 299 k.s.h. musi być interpretowany w sposób ścisły, tym bardziej, że art. $276 \S 1$ k.s.h. ustanawia zasadę, że to członkowie zarządu są likwidatorami, chyba że odmienne regulacje znajdą się w umowie spółki z o.o. lub uchwale wspólników. W następstwie zaaprobowania stanowiska, zgodnie z którym członek RN delegowany do wykonywania zadań w zarządzie nie jest jego członkiem, dochodzi zatem do sytuacji, że nie ponosi on odpowiedzialności na podstawie art. 299 k.s.h. Osoba delegowana nie poniesie odpowiedzialności, mimo iż wykonuje identyczne czynności co członek zarządu powołany w tradycyjnej procedurze, który tę odpowiedzialność będzie ponosił. Taka interpretacja wydaje się niesprawiedliwa i stanowi przejaw nierównego traktowania podmiotów znajdujących się w takiej samej sytuacji ${ }^{56}$. Obecnie nie ma normy prawnej nakładającej odpowiedzialność na osoby delegowane do wykonywania czynności zarządu.

Należy sądzić, że okolicznością świadczącą o tożsamym położeniu (statusie delegowanego), powinien być zakres wykonywanych czynności (obowiązków), nie zaś sposób (procedura) powołania. Słuszna wydaje się teza, że delegowanie stanowi źródło nawiązania stosunku członkostwa w zarządzie, więc osoba delegowana posiada status (czasowe członkostwo) w zarządzie ${ }^{57}$. Innymi słowy kluczowe powinno być umocowanie do występowania w imieniu spółki w określonym zakresie spraw, a nie źródło umocowania (organ podejmujący decyzję) do występowania w charakterze zarządcy ${ }^{58}$.

Trzeba dostrzec, że określenie statusu członka RN delegowanego do wykonywania funkcji zarządu jest istotne z punktu widzenia prawidłowości funkcjonowania zarówno zarządu, jak i RN, w szczególności, gdy składy obu organów zostały w umowie uregulowane w sposób sztywny (nie widełkowy). Zmniejszenie się liczby członków poniżej określonej liczby sprawia, że organ nie jest

55 Ustawa z 15 maja 2015 r. Prawo restrukturyzacyjne, Dz.U. z 2019 r., poz. 243 ze zm.

56 A. Nowacki, Delegowanie..., s. 15, którego zdaniem osoba delegowana do wykonywania funkcji zarządu nie może odpowiadać według przepisów o odpowiedzialności członków zarządu, gdyż członkiem tym nie jest. Autor pogląd swój odnosi do odpowiedzialności karnej, której podstawą nie może być stosowany analogicznie przepis, jednak pogląd ten odnosi się również do odpowiedzialności cywilnoprawnej, w tym m.in. art. 291 k.s.h. lub 299 k.s.h.

57 Wyrok NSA w Warszawie z 12 kwietnia 2013 r. I GSK 1263/11, Lex nr 1336162.

58 Wyrok SN z 12 maja 2011 r., II UK 308/10, Lex nr 1165771. 
prawidłowo obsadzony (organ kadłubowy), a wobec tego jest niezdolny do dokonywania czynności w imieniu spółki.

W końcu zwrócić należy uwagę, że w rezultacie delegowania członek RN nabywa uprawnienia do wykonywania czynności zarządu, tj. może prowadzić sprawy spółki i ją reprezentować. Wykonywanie czynności zarządczych oddziałuje na wiele sfer aktywności spółki, wyłączając jednocześnie bezstronność osoby delegowanej. Jednoczesne wykonywanie czynności zarządu i kontroli sprzeciwia się regule $\mathrm{z}$ art. $214 \S 1$ k.s.h. zakazującej łączenia członkostwa w tych organach (zakaz dotyczy wszystkich czynności kontrolnych i ma bezwzględny charakter). $\mathrm{Z}$ tego względu członek RN delegowany do wykonywania zadań zarządu na czas sprawowania funkcji w zarządzie nie powinien posiadać kompetencji do wykonywania prac $\mathrm{w} \mathrm{RN}^{59}$. Co istotne, $\mathrm{w}$ takiej sytuacji mandat członka $\mathrm{RN}$ trwa, a zatem nie jest możliwe powołanie nowego. W związku z tymi trudnościami delegowanie jawi się jako instytucja kłopotliwa, niezbyt prosta w codziennym stosowaniu dla spółki. De lege ferenda warto uwzględnić w k.s.h. zawieszenie ex lege członkostwa w RN na czas delegowania.

$\mathrm{Na}$ marginesie warto dostrzec, że na skutek delegowania członek RN de facto może kontrolować swoje działania, chociaż sytuacja taka może zaistnieć w zwykłym toku procedowania i obsadzania mandatów w organach spółki, gdyż k.s.h. nie wprowadza zakazu pełnienia funkcji w RN bezpośrednio po wykonywaniu mandatu członka zarządu. De lege lata nie ma normy prawnej nakazującej powstrzymanie się od oceny wcześniejszych poczynań, co wydaje się pożądane de lege ferend $a^{60}$.

W związku z powyżej czynionymi uwagami wskazać należy, że art. 214 k.s.h. wprowadza na gruncie spółki z o.o. zakaz łączenia stanowisk w zarządzie i RN. Możliwość delegowania członka RN przy przyjęciu poglądu o niewygasaniu mandatu w organie nadzoru sprzeciwia się tej regulacji. Oponenci tego zapatrywania wskazują, że w spółce akcyjnej istnieje jego odpowiednik - tj. art. 387 k.s.h. ${ }^{61}$, nie zauważając przy tym istotnej, jak się wydaje, różnicy, że na gruncie spółki

59 M. Chomiuk, w: Kodeks spótek handlowych. Komentarz, red. Z. Jara, s. 874; podobnie na gruncie spółki akcyjnej: J. Szwaja, I.B. Mika, w: Kodeks spółek handlowych. Tom III..., s. 729.

60 Swego rodzaju wzorem dla prac nad przedmiotową regulacją mogłyby stanowić art. 209 lub 244 k.s.h.

61 A. Opalski, Komentarz do art. 220 k.s.h., w: Kodeks spótek handlowych. Tom IIA. Spótka z ograniczona odpowiedzialnościa. Komentarz do art. 151-226, red. A. Opalski, Legalis. 
akcyjnej istnieje lex specialis w postaci art. 383 § 1 k.s.h., który wyraźnie zezwala na delegowanie ${ }^{62}$.

\section{Podsumowanie}

Delegowanie członka RN do czasowego wykonywania funkcji zarządu w spółce z o.o. jest instytucją niejednoznaczną. Cechę taką wykazuje nie tylko sama możliwość stosowania delegacji, ale także jej konsekwencje prawne. W pełni uzasadnione jest podnoszenie argumentu o niemożności jej występowania w spółce z o.o. z uwagi na brak normy dopuszczającej możliwość delegowania członków $\mathrm{RN}$ do wykonywania funkcji zarządu. Istniejące przypadki traktować należy jako wykładnię kreującą instytucję nieznajdującą wyraźnej podstawy normatywnej.

Chociaż zajęte stanowisko sprzeciwia się praktycznemu podejściu do zagadnienia, to znajduje jurydyczne oparcie w porządku prawnym (regulacja negatywna). Przede wszystkim ustawodawca normuje spółki kapitałowe w sposób kompleksowy, co czyni wątpliwym sięganie na potrzeby spółki z o.o. do wzorców spółki akcyjnej. Nie uważam, aby spółka z o.o. była „niedoregulowana" i konieczne było sięganie do norm regulujących spółkę akcyjną. Ustawodawca nie posługuje się przepisem odsyłającym, bez którego zwrócenie się do regulacji innej spółki nie wydaje się możliwe. Naturą spółek kapitałowych jest rozdzielenie kompetencji pomiędzy ich organami. Wszelkie odstępstwa w tej materii traktować należy w sposób możliwie precyzyjny. Każdy organ spółki ma swoje własne, ustawowo zastrzeżone kompetencje, które mogą być modyfikowane w przypadku występowania w tym zakresie wyraźnej normy prawnej. Przepis art. 383 k.s.h. pozwala przyjąć wyjątkowość regulacji, która nie może być w sposób zupełnie dowolny przenoszona na spółkę z o.o., w szczególności przez odwołanie się do zasady swobody umów. Tytułem przykładu można podać Rekomendację w zakresie projektu przepisów regulujących prostą spółkę akcyjną, gdzie dla PSA będącej kategorią spółki akcyjnej została wyraźnie przewidziana samodzielna regulacja w materii delegowania, nie zaś odesłanie do art. 383 k.s.h.

Jest zastanawiające, jak daleko może sięgać dokonywana przez wspólników spółki z o.o. twórcza wykładnia kreująca instytucje wyraźnie niewskazane w ustawie. Swoboda wspólników in casu w tym zakresie osłabia argument racjonalności ustawodawcy i wynikający z niego wniosek, że brak regulacji nie jest

62 A. Nowacki, Komentarz... 
przypadkowy, a w pełni zamierzony. Trzeba dodać, że z przepisów k.s.h. można wnosić, że na skład zarządu, a tym samym kształt i obraz spółki z o.o. zasadniczo powinni mieć wpływ wspólnicy spółki. W końcu mimo istniejących już na gruncie k.h. rozbieżności co do dopuszczalności delegowania w spółce z o.o. ustawodawca nie wypowiedział się w tym zakresie w k.s.h. Swoiste uzupełnienie wskazanych argumentów stanowią niejasności występujące w związku z oceną delegowania, konsekwencji prawnych jego zastosowania, jak również określenia statusu delegowanego członka RN.

Liczne wątpliwości w zakresie delegowania do czasowego wykonywania czynności w zarządzie spółki z o.o., będące następstwem twórczych procesów wykładni prawa, powodują, że ich definitywne usunięcie możliwe jest wyłącznie przez ingerencję ustawodawcy $\mathrm{w}$ tekst k.s.h. Delegowanie w praktyce wywołuje wiele niejasności. Pomimo zajętego stanowiska i zgłoszonych uwag w mojej ocenie nowelizacja oddziału II k.s.h. pt. „Nadzór”, a dokładnie jego art. 220 k.s.h., powinna zmierzać w kierunku dopuszczenia możliwości delegowania członka RN do czasowego wykonywania czynności w zarządzie (na wzór art. $383 \S 1$ k.s.h.), z jednoczesnym precyzyjnym określeniem granic i przesłanek delegowania oraz rozstrzygnięciem statusu osoby delegowanej. Chociaż postulowana zmiana mogłaby spotkać się z zarzutem „ustawowej nadregulacji”, to trzeba pamiętać, że pewność prawa jest wartością samą w sobie, co wymaga stanowczości i precyzyjności.

\section{Literatura}

Allerhandt M., Kodeks handlowy. Księga pierwsza Kupiec. Komentarz, Lwów 1935 (reprint Warszawa 1991).

Bieniak J., w: Spółka akcyjna. Komentarz, red. J. Bieniak, M. Bieniak, Warszawa 2005.

Chomiuk M., w: Kodeks spółek handlowych. Komentarz, red. Z. Jara, Warszawa 2014.

Dziurzyński T., w: Kodeks handlowy. Komentarz, red. T. Dziurzyński, Z. Fenichel, M. Honzatko, Łódź 1995.

Kopaczyńska-Pieczniak K., w: Kodeks spółek handlowych t. I. Komentarz do art. 1-150, red. A. Kidyba, Warszawa 2017.

Kopaczyńska-Pieczniak K., w: Kodeks spółek handlowych t. II. Komentarz do art. 151-300, red. A. Kidyba, Warszawa 2018.

Kwaśnicki R.L., Autonomia woli w kształtowaniu postanowień umowy (aktu założycielskiego) spółki z o.o., „Prawo Spółek” 2003, nr 7-8. 
Kwaśnicki R.L., Korniluk M., Delegowanie członka rady nadzorczej spółki akcyjnej do czasowego wykonywania funkcji członka zarzadu, „Monitor Prawniczy” 2009, nr 1, Legalis.

Litwińska M., Glosa do wyroku Sądu Najwyższego z 5 maja 1996 r., sygn. akt: II CRN 29/96, „Przegląd Prawa Handlowego” 1997, nr 1.

Morawski L., Zasady wykładni prawa, Toruń 2010.

Namitkiewicz J., Kodeks handlowy. Komentarz t. III, Warszawa 1937.

Naworski J.P., Delegowanie członków organów nadzoru spółki kapitałowej do zarządu, „Prawo Spółek” 2002, nr 2.

Nowacki A., Delegowanie członków rady nadzorczej do czasowego wykonywania czynności członków zarządu, „Przegląd Prawa Handlowego” 2010, nr 10.

Nowacki A., Komentarz do art. 220 KSH, w: Spółka z ograniczona odpowiedzialnością. Tom I. Komentarz do art. 151-226 KSH, Legalis 2018.

Opalski A., w: Kodeks spótek handlowych. Tom IIIA. Spółka akcyjna. Komentarz do art. 301-392, red. A. Opalski, Warszawa 2016.

Opalski A., Komentarz do art. 220 k.s.h., w: Kodeks spółek handlowych. Tom IIA. Spótka z ograniczona odpowiedzialnością. Komentarz do art. 151-226, red. A. Opalski, Legalis.

Rachwał A., w: System Prawa Handlowego, t. 2 A Prawo spółek handlowych, red. S. Włodyka, Warszawa 2007.

Rekomendacja Zespotu do opracowania rekomendacji w zakresie projektu przepisów regulujących prosta spółkę akcyjna (propozycja zmian w Kodeksie spótek handlowych), niepublikowany.

Rodzynkiewicz M., Kodeks spółek handlowych. Komentarz, Warszawa 2012.

Romanowski M., w: System Prawa Prywatnego t. 16. Prawo spółek osobowych, red. A. Szajkowski, Warszawa 2008.

Siemiątkowski T., Potrzeszcz R., w: Kodeks spółek handlowych. Komentarz, t. 1, red. T. Siemiątkowski, R. Potrzeszcz, Warszawa 2011.

Strzelczyk K., w: Kodeks spółek handlowych. Komentarz, t. 2, red. T. Siemiątkowski, R. Potrzeszcz, Warszawa 2011.

Strzępka J.A., Zielińska E., w: Kodeks spótek handlowych. Komentarz, red. J.A. Strzępka, Warszawa 2015.

Strzępka W., Rozszerzenie uprawnień rady nadzorczej w spółce z o.o., „Prawo Spółek” 2001, nr 5. 
Szajkowski A., Tarska M., Szumański A., w: Kodeks spółek handlowych t. II. Spółka z ograniczona odpowiedzialnością. Komentarz do art. 151-300, red. S. Sołtysiński, A. Szajkowski, A. Szumański, J. Szwaja, Warszawa 2014.

Szajkowski A., Tarska M., Szumański A., w: Kodeks spółek handlowych. Tom III. Spótka akcyjna. Komentarz do art. 301-490, red. S. Sołtysiński, A. Szajkowski, A. Szumański, J. Szwaja, Warszawa 2013.

Szumański A., Ograniczenia wolności umów w prawie spółek handlowych, „Gdańskie Studia Prawnicze" 1999, t. II.

Szumański A., w: Prawo spółek, red. W. Pyzioł, A. Szumański, I. Weiss, Warszawa 2014.

Szwaja J., Mika I.B., w: Kodeks spótek handlowych. Tom III. Spółka akcyjna. Komentarz do art. 301-490, red. S. Sołtysiński, A. Szajkowski, A. Szumański, J. Szwaja, Warszawa 2013.

Tarska M., Zakres swobody umów w spółkach handlowych, Warszawa 2012.

Tomkiewicz J., Bloch J., w: Spółki z ograniczona odpowiedzialnością. Kodeks handlowy art. 158-306 i 491-497. Komentarz, red. J. Tomkiewicz, J. Bloch, Warszawa 1934.

\section{Akty prawne}

Rozporządzenie Prezydenta Rzeczypospolitej z 27 czerwca 1934 r. Kodeks Handlowy, Dz.U. z 1934 r., nr 57, poz. 502 ze zm.

Ustawa z 15 maja 2015 r. Prawo restrukturyzacyjne, Dz.U. z 2019 r., poz. 243 ze zm.

Ustawa z 20 grudnia 1996 r. o gospodarce komunalnej, Dz.U. z 2019 r., poz. 712 ze zm.

Ustawa z 20 sierpnia 1997 r. o Krajowym Rejestrze Sądowym, Dz.U. z 2019 r., poz. 1500 ze zm.

Ustawa z 23 kwietnia 1964 r. Kodeks cywilny, Dz.U. z 2019 r., poz. 1145 ze zm.

Ustawa z 15 września 2000 r. Kodeks spółek handlowych, Dz.U. z 2019 r., poz. 505 ze zm.

\section{Orzecznictwo}

Wyrok NSA w Warszawie z 12 kwietnia 2013 r., I GSK 1263/11, Lex nr 1336162.

Wyrok SN z 12 maja 2011 r., II UK 308/10, Lex nr 1165771.

Wyrok SN z 6 czerwca 2013 r., II UK 329/12, Lex nr 1331292. 


\title{
DELEGATING MEMBERS OF THE SUPERVISORY BOARD \\ OF A LIMITED LIABILITY COMPANY TO ACT \\ IN THE MANAGEMENT BOARD
}

\begin{abstract}
Summary
So far, it has not been decided whether a limited liability company may delegate a member of the supervisory board to temporarily perform the duties of a member of the management board. Practice is in favour of this possibility, while the doctrine expresses diverse views.

The purpose of this paper is to analyze the subject matter in question. The principle of freedom of contract under company law and differences in the regulation of partnerships and capital companies, including the method of appointing the management board, are pointed out. It discusses the consequences of the assessment of delegation in the absence of explicit regulation, as well as the absence of a referral to use Article 383 of the Commercial Companies Code analogically. It demonstrates a number of doubts which are caused by delegation (when the thesis about its admissibility is approved), in particular the status of the delegate (the question of the continued existence of a legal relationship in the supervisory board). The paper employs the dogmatic method.

The conclusion is that delegating a member of the supervisory board in a limited liability company de lege lata is not acceptable. However, it is desirable, which is why it should have a regulation modelled on Article $383 \S 1$ CCC.
\end{abstract}

Keywords: limited liability company, supervisory board, management board, the principle of freedom of contract 